\title{
Role of Interferon-Gamma +874 A/T Single-Nucleotide Polymorphism and Tuberculosis Susceptibility of Pediatric Population in North Sumatera, Indonesia
}

\author{
Rini Savitri Daulay ${ }^{1 *}$ (i), Rina Amalia C. Saragih ${ }^{1}$, Ridwan Muchtar Daulay ${ }^{1}$, Ratna Akbari Ganie ${ }^{2}$, Gino Tann $^{2}$, Bambang Supriyatno $^{3}$ \\ ${ }^{1}$ Department of Child Health, Faculty of Medicine, Universitas Sumatera Utara, Medan, Indonesia; ${ }^{2}$ Department of Clinical \\ Pathology, Faculty of Medicine, Universitas Sumatera Utara, Medan, Indonesia; ${ }^{3}$ Department of Child Health, Faculty of \\ Medicine, Universitas Indonesia, Jakarta, Indonesia
}

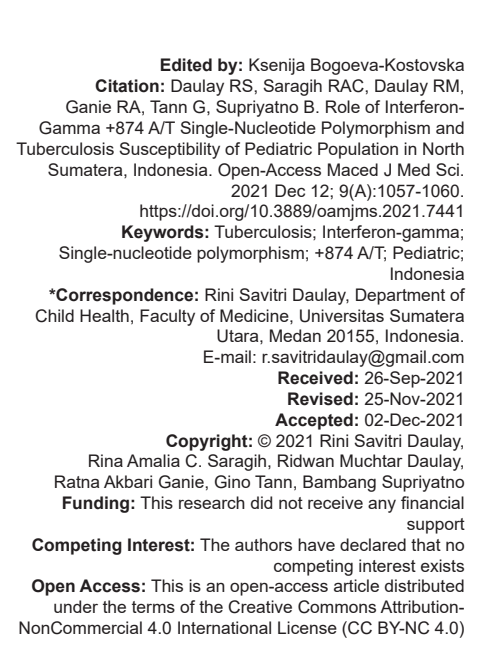

\section{Introduction}

Tuberculosis (TB) remains to be the leading cause of morbidity and mortality worldwide, particularly in developing country. According to World Health Organization data, Indonesia is on the second ranked country with the highest burden of TB. The incidence of TB in Indonesia include HIV is $312 / 100,000$ population [1]. Host genetic factors play a pivotal and complex role in host susceptibility to TB disease. Therefore, the identification of host genes responsibility to TB should provide a significant contribution to understanding the pathogenesis of TB and lead to development management of TB [2].

Cellular immunity was mediated the host immune response against Mycobacterium tuberculosis (M. tuberculosis) in which cytokine and $\mathrm{T}$ helper 1 cells play an important role. Interferon-gamma $(\mathrm{IFN}-\gamma)$ is considered to be a crucial protein that synthesized and released by certain immune cells in response to the presence of pathogen, such as virus or intracellular bacteria. IFN- $\gamma$ is one of the main cytokines involved in the protective immune response against mycobacterial infection. IFN- $\gamma$ primarily produced by CD4 and CD8 T lymphocytes and natural killer (NK) cells. The primary function of IFN- $\gamma$ is to activate and enable the macrophages to exert its microbicide role function. IFN- $\gamma$ also induced the gene transcription in macrophages, including the production of antimicrobial molecule (oxygen free radical and nitric oxide) that represents as the best mechanism to eliminating M. tuberculosis [3], [4].

To date, the role of $+874 \mathrm{~A} / \mathrm{T}$ single-nucleotide polymorphism (SNP) and the TB disease susceptibility continues to be controversial. Investigating the role of +874 A/T SNP and TB disease susceptibility of pediatric population in Indonesia is important to understanding role of $+874 \mathrm{~A} / \mathrm{T}$ SNP in this specific population. The aim of this study was to investigate the 
role of +874 A/T SNP and TB disease susceptibility of pediatric population in North Sumatera, Indonesia.

\section{Methods}

\section{Study setting and ethnic statement}

A case-control study was conducted between January and November 2016. During the study period, we recruited subjects from two general hospitals and seven primary health care in Medan and Batubara, North Sumatera, Indonesia. Inclusion criteria were children aged two months to 14 years old diagnosed with TB and whose parents or caregivers had informed consent to participate. Subjects were withdrawn from the study if immunodeficiency condition was found or the patients suffered from other infection disease.

Subject composed of 51 children with TB and 51 healthy controls. Diagnosis of TB based on clinical manifestation, positive tuberculin skin test, and chest $X$-ray, and, in lymphadenitis TB case, the finding of suggestive lymphadenitis TB from fineneedle aspiration biopsy. The study was approved by the Ethical Committee of Universitas Sumatera Utara, Medan, North Sumatera, and written informed consent was given from all the parents or guardians.

\section{DNA isolation and genotyping}

DNA samples were obtained from all of the subjects. The genotyping was performed using amplification refractory mutational system-polymerase chain reaction (ARMS-PCR) that modified from the previous study by Pravica et al. ARMS-PCR method is practical for typing biallelic cytokine polymorphisms that are either directly or indirectly involved in regulation of gene expression [5].

DNA was amplified in a total $20 \mu \mathrm{L}$ reaction and the final concentrations of regents consist of $2 \mu \mathrm{L}$ total DNA extraction, $10 \mu \mathrm{L}$ of reaction mixture, $3.2 \mu \mathrm{L}$ sucrose $(53 \%), 0.8 \mu \mathrm{L}$ NF water, and $1 \mu \mathrm{L}$ from each primer (generic primer, allele A or allele $\mathrm{T}$ primer, internal control primer 1, and internal control primer 2).

The protocol for the PTC-100 PCR was as follows: $95^{\circ} \mathrm{C}$ for $1 \mathrm{~min}, 95^{\circ} \mathrm{C}$ for $15 \mathrm{~s}, 62^{\circ} \mathrm{C}$ for $50 \mathrm{~s}$, and $72^{\circ} \mathrm{C}$ for $40 \mathrm{~s}$ all were mixed for 10 cycles each; $95^{\circ} \mathrm{C}$ for $20 \mathrm{~s}, 56^{\circ} \mathrm{C}$ for $50 \mathrm{~s}$, and $72^{\circ} \mathrm{C}$ for $50 \mathrm{~s}$ were all mixed for 20 cycles each [5].

The primer sequences were as follows: IFN- $\gamma$ generic primer, 5'tcaacaaagctgatactcca-3'; IFN- $\gamma$ primer T allele 5'ttcttacaacacaaaatcaaatct-3'; IFN- $\gamma$ primer A allele 5'-ttcttacaacacaaaatcaaatca-3'; internal control primer 1, 5-gccttcccaaccattccctta-3'; and internal control primer 2, 5'-tcacggatttctgttgtgtttc-3'. The amplified products were monitored by electrophoresis on a $2 \%$ agarose gel containing ethidium bromide [5].

\section{Statistical analysis}

Statistical analysis was performed by SPSS software version 22. The genotyping of SNP +874 A/T was analyzed between children with TB and healthy controls by Chi-square test. Mann-Whitney U-test was used to investigate IFN- $\gamma$ levels between children with TB and healthy controls. Significant result will be considered whereas $p<0.05$ was considered.

\section{Results}

During the study period, 51 children diagnosed with TB were recruited for the subjects and 51 healthy children were recruited for the control group. Epidemiological profile of the subjects is shown in Table 1. Most of TB patients were female $(72.5 \%)$ with age below than 5 years old or above 10 years old age $(54.9 \%)$.

Table 1: Subjects profile and characteristics

\begin{tabular}{lll}
\hline Characteristics & TB patients, $\mathrm{n}(\%)$ & Healthy control, $\mathrm{n}(\%)$ \\
\hline Gender & $14(27.5)$ & $27(52.9)$ \\
$\quad$ Male & $37(72.5)$ & $24(47.1)$ \\
Female & & \\
Age & $28(54.9)$ & $34(66.7)$ \\
$<5$ yo or $>10$ yo & $23(45.1)$ & $17(33.3)$ \\
$5-10$ yo & $51(100)$ & $51(100)$ \\
Total &
\end{tabular}

The result of this study revealed that the presence of $\mathrm{AA}, \mathrm{AT}$, and TT genotype in TB patients was $31(60.8 \%), 20(39.2 \%)$, and $0(0 \%)$, respectively ( $p=0.023$ ), as shown in Table 2. Significant decreased production of IFN- $\gamma$ levels $(p=0.042)$ was found in TB patients 9.41 (1.10-28.06) pg/ml (Table 3).

Table 2: Genotype of +874 A/T SNP

\begin{tabular}{llll}
\hline Genotype & Case, $\mathrm{n}(\%)$ & Control, $\mathrm{n}(\%)$ & $\mathrm{p}$ \\
\hline AA & $31(60.8)$ & $19(37.2)$ & 0.023 \\
AT & $20(39.2)$ & $29(56.9)$ & \\
TT & $0(0)$ & $3(5.9)$ & \\
Total & 51 & 51 & \\
\hline SNP. Single-nucleotide polymorphism. & &
\end{tabular}

\section{Discussion}

Susceptibility to infectious disease is influenced by genetic background of the immune regulatory cytokines. SNP on $+874 \mathrm{~A} / \mathrm{T}$ has been linked Table 3: IFN- $y$ levels of TB patients and healthy control

\begin{tabular}{lll}
\hline IFN-y level & Median (min-max) & $\mathrm{p}$ \\
\hline IFN- level of TB patients & $9.41(1.10-28.06)$ & $0.042^{*}$ \\
IFN- $y$ level of healthy control & $6.30(1.30-89.76)$ & \\
\hline IFN-Y: Interferon-gamma. & &
\end{tabular}


to increased TB disease susceptibility, but the data still controversial [6], [7]. The previous study by Shen et al. reported that $+874 \mathrm{~A} / \mathrm{T}$ SNP was more frequent among TB patient, especially in females, but the difference was not significant [8]. Ben-Selma et al. found that +874 AA genotype was significantly associated with increased risk of TB in Tunisian patients [9]. This finding is consistent with a study of Egyptian children with TB [10].

By contrast, the previous study reported no association between +874 A/T SNP and TB disease susceptibility. A study by Etokebe et al. suggested no association of +874 A/T and TB disease susceptibility in Croatian Caucasian population [11].

In our study, a case-control study was performed to investigate the role of $+874 \mathrm{~A} / \mathrm{T}$ SNP and TB disease susceptibility of pediatric population in North Sumatera, Indonesia. We found AA genotype significantly more frequent among children with TB, our finding was in agreement with several previous studies that reported AA genotype increased risk for develop active TB in Brazilian, Taiwanese, and Southeast Chinese population [12], [13], [14]. A previous study of Iranian population also showed AA genotype as a risk factor for TB disease [15].

IFN- $\gamma$ is produced mainly by NK cells and activated $\mathrm{T}$ cells, as a result of the activation of early immune response mechanism and subsequently by antigen-specific $T$ cells during the course of $M$. tuberculosis infection. Therefore, persons having a genotype associated with low IFN- $\gamma$ producer would be expected to increased susceptibility of TB in relation with impair the activation of macrophages [10].

Our study results demonstrated lower IFN- $\gamma$ levels among pediatric TB population 9.41 (1.10-28.06) $\mathrm{pg} / \mathrm{ml}$ compared to control group 6.30 (1.30-89.76) $\mathrm{pg} / \mathrm{ml}, \mathrm{p}=0.042$. Low level of IFN- $\gamma$ in TB patients will cause decreased of the activation of macrophages, leading to occurred of TB disease [4].

To the best of our knowledge, this is the first study on +874 A/T SNP and TB disease susceptibility in Indonesia. Our finding indicates significant role of +874 A/T SNP and TB disease susceptibility of pediatric population in Indonesia and lower IFN- $\gamma$ levels among pediatric TB population.

\section{Conclusion}

Our study demonstrated predominantly $A A$ genotype as a significant evidence of the role $+874 \mathrm{~A} / \mathrm{T}$ SNP and TB disease susceptibility of pediatric population in North Sumatera, Indonesia. Significant decreased production of IFN- $\gamma$ was also found among pediatric TB.

\section{References}

1. World Health Organization. Global Tuberculosis Report Geneva: World Health Organization; 2020. Available from: https://www.who.int/teams/global-tuberculosis-programme/ tb-reports [Last accessed on 2021 Sep 10]

2. Azad A, Sadee W, Schlesinger L. Innate immune gene polymorphisms in tuberculosis. Infect Immun. 2012;80(10):3343-59. http://doi.org/10.1128/IAI.00443-12 PMid:22825450

3. Cavalcanti Y, Brelaz M, Lemoine Neves J, Ferraz J, Pereira V. Role of TNF-alpha, IFN-gamma, and IL-10 in the development of pulmonary tuberculosis. Pulm Med. 2012;2012:745483. http://doi.org/10.1155/2012/745483

PMid:23251798

4. Weiss $\mathrm{G}$, Schaible U. Macrophage defense mechanisms against intracellular bacteria. Immunol Rev. 2015;264(1):182-203. http:// doi.org/10.1111/imr.12266

PMid:25703560

5. Pravica V, Perrey C, Stevens A, Lee J, Hutchinson I. A single nucleotide polymorphism in the first intron of the human IFN- $\gamma$ gene. Hum Immunol. 2000;61(9):863-6. http://doi.org/10.1016/ s0198-8859(00)00167-1

PMid:11053629

6. Möller M, Hoal E. Current findings, challenges and novel approaches in human genetic susceptibility to tuberculosis. Tuberculosis. 2010;90(2):71-83. http://doi.org/10.1016/j.tube.2010.02.002 PMid:20206579

7. Singh D, Bagam P, Sahoo M, Batra S. Immune-related gene polymorphisms in pulmonary diseases. Toxicology. 2017;383:24-39. http://doi.org/10.1016/j.tox.2017.03.020 PMid:28366820

8. Shen C, Jiao W, Feng W, Wu X, Xiao J, Miao Q, et al. IFNG polymorphisms are associated with tuberculosis in Han Chinese pediatric female population. Mol Biol Rep. 2013;40(9):5477-82. http://doi.org/10.1007/s11033-013-2647-7

PMid:23737189

9. Selma W, Harizi H, Bougmiza I, Hannachi N, Kahla I, Zaieni R, et al. Interferon gamma +874 T/A polymorphism is associated with susceptibility to active pulmonary tuberculosis development in Tunisian patients. DNA Cell Biol. 2011;30(6):379-87. http:// doi.org/10.1089/dna.2010.1157

PMid:21332391

10. Mosaad Y, Soliman O, Tawhid Z, Sherif D. Interferongamma +874 T/A and interleukin-10-1082 A/G single nucleotide polymorphism in Egyptian children with tuberculosis. Scand J Immunol. 2010;72(4):358-64. http://doi. org/10.1111/j.1365-3083.2010.02426.x

PMid:20883321

11. Etokebe G, Bulat-Kardum L, Johansen M, Knezevic J, Balen S, Matakovic-Mileusnic N, et al. Interferon-gamma gene (T874A and G2109A) polymorphisms are associated with microscopypositive tuberculosis. Scand J Immunol. 2006;63(2):136-41. http://doi.org/10.1111/j.1365-3083.2005.01716.x PMid:16476013

12. Amim L, Pacheco A, Fonseca-Costa J, Loredo C, Rabahi M Melo M, etal. Role of IFN- $\gamma+874$ T/A single nucleotide polymorphism in the tuberculosis outcome among Brazilians subjects. Mol Biol Rep. 2007;35(4):563-6. http://doi.org/10.1007/s11033-007-9123-1 PMid: 17682837

13. Lee $\mathrm{S}$, Chuang $\mathrm{T}$, Huang $\mathrm{H}$, Lee $\mathrm{K}$, Chen $\mathrm{T}$, Kao $\mathrm{Y}$, et al. Interferon gamma polymorphisms associated with susceptibility to tuberculosis in a Han Taiwanese population. J Microbiol Immunol 
Infect. 2015;48(4):376-80. http://doi.org/10.1016/j.jmii.2013.11.009 PMid:24529854

14. Ding S, Li L, Zhu X. Polymorphism of the interferon- $\gamma$ gene and risk of tuberculosis in a Southeastern Chinese population. Hum Immunol. 2008;69(2):129-33. http://doi.org/10.1016/j.humimm.2007.11.006 PMid:18361939
15. Naderi M, Hashemi M, Taheri M, Pesarakli H, Eskandari-Nasab E, Bahari G. CD209 promoter 336 A/G (rs4804803) polymorphism is associated with susceptibility to pulmonary tuberculosis in Zahedan, Southeast Iran. J Microbiol Immunol Infect. 2014;47(3):171-5. http://doi.org/10.1016/j.jmii.2013.03.013 PMid:23751770 